MATHEdunesa

Jurnal IImiah Pendidikan Matematika Volume 10 No.1 Tahun 2021

ISSN :2301-9085

\title{
EFEKTIVITAS PEMBELAJARAN DARING PADA MATERI PERSAMAAN DAN FUNGSI KUADRAT
}

\author{
Rizcha Handini Setiani \\ Pendidikan Matematika, Fakultas Matematika dan Ilmu Pengetahuan Alam, Universitas Negeri Surabaya,
} rizcha.17030174004@mhs.unesa.ac.id

\section{Ika Kurniasari}

Pendidikan Matematika, Fakultas Matematika dan Ilmu Pengetahuan Alam, Universitas Negeri Surabaya, ikakurniasari@unesa.ac.id

\section{ABSTRAK}

Perkembangan pendidikan saat ini dipengaruhi oleh pesatnya kemajuan teknologi informasi serta komunikasi. Salah satu teknologi informasi yang turut berperan dalam dunia pendidikan yaitu pembelajaran daring. Penelitian ini bertujuan untuk mengetahui efektivitas pembelajaran daring pada materi persamaan dan fungsi kuadrat. Keefektifan pembelajaran daring ditinjau dari empat aspek, yakni: kegiatan guru, kegiatan peserta didik, ketuntasan belajar peserta didik, dan respon peserta didik terhadap pembelajaran. Suatu pembelajaran dikatakan efektif jika paling sedikit tiga dari empat aspek di atas terpenuhi, dengan ketentuan aspek ketuntasan belajar peserta didik terpenuhi. Learning Management System (LMS) yang digunakan untuk penelitian ini adalah Google Meet, Google Classroom, dan Google Jamboard. Penelitian ini merupakan penelitian deskriptif kuantitatif. Subjek dalam penelitian ini yakni peserta didik kelas XI Teknik Bisnis Sepeda Motor (TBSM) 2 yang terdiri dari 35 peserta didik yang diambil secara acak dari seluruh peserta didik kelas XI SMK Negeri 2 Tulungagung. Setelah penelitian ini dilakukan maka dapat disimpulkan pembelajaran daring pada materi persamaan dan fungsi kuadrat dikatakan tidak efektif karena tidak tuntasnya hasil belajar peserta didik dan kurang positifnya respon peserta didik terhadap pembelajaran. Perihal ini diakibatkan bermacam aspek, antara lain minimnya uraian yang komprehensif serta sederhana dari guru karena pada penelitian ini guru menjelaskannya terlalu panjang sehingga peserta didik kesulitan memahami materi yang diberikan dan diperlukan menggunakan media yang menarik untuk belajar mandiri seperti video pembelajaran dan game matematika, rendahnya aspek afektif serta psikomotorik pada pembelajaran dimana peserta didik kesulitan dalam mengerjakan tes hasil belajar, sinyal internet, rendahnya atensi peserta didik terhadap pembelajaran daring, serta pembelajaran daring belum diterapkan sepenuhnya di sekolah.

Kata Kunci : Efektivitas, Pembelajaran, Daring.

\section{U niversitas ABSTRACT}

The development of education is currently influenced by the rapid advancement of information and communication technology. One of the information technologies that play a role in the world of education is online learning. This study aims to determine the effectiveness of online learning on equation materials and quadratic functions. The effectiveness of learning is reviewed from four aspects, including: teacher activities, student activities, students' learning completion, and students' response to learning. A learning is said to be effective if at least three of the above four aspects are fulfilled, provided that the aspects of learners' learning completion are fulfilled. The Learning Management System (LMS) used for this research is Google Meet, Google Classroom, and Google Jamboard. This research is descriptive quantitative research. The subjects in this study were students of class XI Motorcycle Business Engineering (TBSM) 2 consisting of 35 students drawn randomly from all students of class XI SMK Negeri 2 Tulungagung. After this research is done, it can be concluded that online learning on equation materials and quadratic functions is said to be ineffective 
Volume 10 No. 1 Tahun 2021, HAL 137-

because of the incomplete learning outcomes of students and the lack of positive response of learners to learning. This subject is due to various aspects, including the lack of a comprehensive and simple description of the teacher because in this study the teacher explained it too long so that students have difficulty understanding the material provided and needed to use interesting media for self-learning such as learning videos and math games, low affective and psychomotor aspects of learning where learners have difficulty in working on the test of learning results, internet signals, low student attention to online learning, and online learning have not been fully implemented in schools.

Keywords: Effectiveness, Learning, Online.

\section{PENDAHULUAN}

Pembelajaran matematika merupakan salah satu mata pelajaran yang dipelajari di sekolah. Pembelajaran matematika di sekolah tidak hanya untuk penguasaan materi matematika, namun juga materi matematika diposisikan sebagai alat dan sarana bagi peserta didik untuk meningkatkan kemampuannya. Pembelajaran matematika pada dasarnya memiliki ciri-ciri abstrak serta konsep dan prinsip hierarkis (Wiryanto, 2020). Hal ini membuat banyak peserta didik kesusahan dalam mempelajari matematika. Penguasaan materi peserta didik menunjukkan keberhasilan pembelajaran matematika di sekolah. Salah satu faktor keberhasilan dalam proses pembelajaran adalah kemampuan guru merencanakan dan melaksanakan pembelajaran. Guru memegang peranan dan kedudukan penting dalam proses pendidikan (Anwar, 2012). Guru dituntut untuk menguasai serta meningkatkan tata cara proses pembelajaran yang sesuai dengan ciri mata pelajaran agar tujuan pembelajaran bisa tercapai secara efisien.

Pembelajaran matematika yang sebelumnya

dilakukan secara langsung dengan tatap muka antara guru dan peserta didik, saat ini berganti sejak adanya Coronavirus Disease 2019 (Covid-19). Covid-19 sendiri ialah tipe baru virus corona yang ditemukan di Wuhan, China pada 2019 lalu. Sejak itu, Covid-19 ditemukan telah menyebar luas, menyebabkan pandemi global terus berlanjut hingga saat ini. Ada laporan data harian di dunia tentang meningkatnya cakupan dan dampak Covid-19. Indonesia secara spontan menerapkan kebijakan belajar di rumah, bekerja di rumah dan beribadah di rumah. Dampak wabah ini sangat luar biasa, terutama di bidang pendidikan. Perihal ini menyebabkan penutupan sekolah-sekolah besar, pesantren, universitas dan pesantren. Peserta didik harus dapat mengikuti pembelajaran berbasis daring sebab tidak mungkin belajar di sekolah yang masih jadi ancaman bagi peserta didik bagaikan tempat penyebaran virus. Perihal tersebut menimbulkan permasalahan baru, salah satunya yakni kesusahan belajar yang dialami peserta didik dalam mengikuti kegiatan pembelajaran.

Perkembangan ilmu pengetahuan dan teknologi saat ini sangat meningkat. Apalagi di bidang teknis yang memenuhi kebutuhan sehari-hari (Nurani, 2020). Penggunaan jaringan internet ditandai dengan penggunaan komputer dan telepon seluler. Usia pengguna internet tergantung pada kegunaannya masing-masing, seperti media sosial, hiburan, permainan, browsing, trading, dan lain-lain. Dalam kasus pembelajaran daring, peserta didik dapat dengan cepat dan langsung berinteraksi dengan teks, gambar, suara, data dan video dua arah di bawah bimbingan guru (Nurani, 2020).

Pembelajaran daring adalah pembelajaran menggunakan internet dalam proses pembelajaran (Dewi, 2020). Pembelajaran daring bisa didefinisikan selaku aktivitas belajar mengajar yang memakai jaringan ataupun koneksi internet untuk komunikasi antara guru serta peserta didik tanpa adanya kontak fisik. Menurut Fitriyani et al. (2020), pembelajaran daring merupakan inovasi pendidikan yang melibatkan unsur teknologi informasi dalam pembelajaran. Menurut Windhiyana (2020) pembelajaran daring dicapai melalui penggunaan koneksi internet, sehingga komunikasi antara pendidik dan peserta didik dapat tercapai tanpa adanya kontak fisik. Sedangkan menurut Dewi (2017) pembelajaran daring merupakan terobosan yang dapat secara efektif dan efisien melaksanakan proses belajar mengajar untuk memenuhi kebutuhan pendidikan peserta didik.

Pembelajaran daring dilakukan untuk memungkinkan komunitas pendidikan terus beroperasi dalam pandemi yang membutuhkan evakuasi fisik. Penerapan pembelajaran daring adalah memberikan peserta didik pengalaman belajar yang bermakna.

Harapannya melalui pembelajaran daring, peserta didik memiliki kesempatan untuk belajar kapanpun dan dimanapun. Pembelajaran daring ini 
merupakan inovasi pendidikan yang dapat memberikan berbagai sumber belajar.. Guru dan peserta didik yang belajar daring dapat menggunakan Google Classroom, zoom, grup whatsapp dan aplikasi lainnya.

Pembelajaran daring sudah memunculkan bermacam permasalahan, serta solusi masih terus dicari. Permasalahan ini termasuk sinyal lemah, aplikasi bermasalah, dan lain-lain. Berdasarkan hasil wawancara, dampak pembelajaran non-tatap muka terhadap peserta didik membuat pengetahuan yang diperoleh kurang ideal. Namun keuntungan dari pembelajaran yang sebenarnya adalah dapat memudahkan peserta didik untuk belajar di rumah dalam situasi apapun. Misalnya, ketika ada peserta didik yang sakit dan tidak dapat keluar rumah, peserta didik tersebut tetap dapat mendengarkan pendapat kelompok belajarnya sehingga dapat terus belajar. Hal ini sejalan dengan penelitian dari Andri Anugrahana (2020) dengan judul "Hambatan, Solusi dan Harapan: Pembelajaran Daring Selama Masa Pandemi Covid-19 oleh Guru Sekolah Dasar" dan Dr. Gogot Suharwoto (2020) dengan judul "Pembelajaran Online di Tengah Pandemi Covid-19, Tantangan yang Mendewasakan".

Perlu waktu lama bagi pembelajaran daring untuk beradaptasi dengan pembelajaran sebelumnya, yakni pembelajaran tatap muka. Banyak guru, peserta didik serta orang tua merasa kewalahan. Perihal ini diakibatkan oleh pergantian mendadak dalam gaya belajar dan persiapan yang tidak memadai dalam pembelajaran daring ini. Dikarenakan adanya gangguan dalam transmisi informasi yang diberikan oleh guru kepada peserta didik, peserta didik kesulitan untuk menguasai materi yang diberikan, salah satu solusinya adalah media pembelajaran seperti Google Meet, Google Jamboard dan Google Classroom.

Ketiga aplikasi tersebut merupakan layanan berbasis internet yang disediakan oleh Google sebagai sistem e-learning. Perbedaannya hanya terletak pada tujuannya. Untuk aplikasi Google Meet, lebih mudah bagi guru untuk menjelaskan pelajaran; untuk aplikasi Google Classroom, lebih mudah bagi guru untuk mengevaluasi setiap kegiatan yang dilakukan peserta didik; untuk aplikasi Google Jamboard, lebih mudah bagi guru untuk menjelaskan atau dalam pengertian ini, itu bisa menggantikan papan tulis. Selain itu, aplikasi tersebut juga memiliki banyak fungsi yang praktis, efisien dan aman. Guru dan peserta didik juga dapat mengajar dan belajar melalui perangkat seluler Android atau iOS.

$$
\text { Peraturan Menteri Pendidikan dan }
$$

Kebudayaan No. 65 Tahun 2013 tentang pemanfaatan teknologi informasi untuk meningkatkan efisiensi dan efektifitas pembelajaran (Permendikbud, 2013). Penggunaan teknologi informasi membuat kegiatan pembelajaran di sekolah menjadi lebih menarik, aktif dan kreatif. Tujuannya untuk mendorong pembelajaran yang efektif dan efisien.

Oleh sebab itu, untuk meningkatkan efektivitas belajar tanpa harus menyita banyak waktu, maka seorang guru harus pandai dalam memilah tata cara apa yang harus digunakan agar cepat ditangkap peserta didik apa yang disampaikannya.

Dalam penelitian ini, efektivitas pembelajaran juga dinilai dari segi guru dan peserta didik sehingga untuk mengukur efektivitas pembelajaran ini ditetapkan empat indikator, yakni:

1. Kegiatan guru dikategorikan baik;

2. Kegiatan peserta didik dikategorikan baik;

3. Ketuntasan belajar peserta didik tuntas secara klasikal;

4. Respon peserta didik dikategorikan positif

Bila tiga dari keempat indikator tersebut terpenuhi, dengan ketentuan indikator nomor tiga harus ikut didalamnya, maka pembelajaran daring pada materi persamaan dan fungsi kuadrat dapat dikatakan efektif (Christiani, 2013).

Dalam penelitian ini, peneliti memberikan materi persamaan dan fungsi kuadrat untuk peserta didik kelas XI SMK Negeri 2 Tulungagung. Peneliti memberikan materi tersebut karena materi ini hampir sama dengan materi yang sudah diberikan di SMP pada saat mâteri persamaan dan fungsi kuadrat dan esensial dalam pelajaran matematika. Menurut hasil penelitian yang dilakukan oleh Nurul Astuty Yensy (2020) menunjukkan bahwa media Whatsapp Group cukup efektif jika dilihat dari ketuntasan belajar peserta didik. Menurut hasil penelitian yang dilakukan oleh Selvi Loviana (2020) menunjukkan bahwa pembelajaran kurang efektif. Menurut hasil penelitian Mega Berliana Yolandasari (2020) yang menyatakan bahwa pelaksanaan pembelajaran daring dalam pembelajaran Bahasa Indonesia di kelas II A kurang efektif dan juga penelitian Jagad Aditya Dewantara (2021) yang menyatakan bahwa 
pembelajaran daring secara terus menerus selama masa pandemi ini sangat tidak efektif.

Kendala-kendala yang terjadi selama proses pembelajaran secara daring harus dijadikan tantangan bagi pendidik untuk mentransformasi pendidikan yang lebih maju lagi. Khususnya dalam pembelajaran matematika yang dirasa oleh sebagian besar peserta didik akan sulit dipelajari jika tidak langsung bertatap muka dengan guru. Maka dari itu, peneliti tertarik melakukan penelitian dengan judul "Efektivitas Pembelajaran Daring pada Materi Persamaan dan Fungsi Kuadrat". Penelitian ini bertujuan untuk mengetahui efektivitas pembelajaran daring pada materi persamaan dan fungsi kuadrat. Yang harapannya dapat membuat peserta didik lebih berperan aktif dalam kegiatan pembelajaran serta meningkatkan pemahaman konsep matematika.

\section{METODE}

Penelitian ini ialah penelitian deskriptif kuantitatif yang bertujuan untuk mendeskripsikan efektivitas pembelajaran daring pada materi persamaan dan fungsi kuadrat yang meliputi kegiatan guru, kegiatan peserta didik, ketuntasan belajar, dan respon peserta didik. Penelitian deskriptif tidak menguji hipotesis, melainkan hanya mendeskripsikan variabel atau kondisi yang ada dalam suatu situasi (Siswono, 2019). Rancangan penelitian yang digunakan dalam penelitian ini merupakan One Shot Case Study. Perangkat pembelajaran yang digunakan dalam penelitian ini berdasarkan Rencana Pelaksanaan Pembelajaran (RPP) yang dibuat sesuai dengan indikator pembelajaran yang hendak dicapai dengan sudah dikonsultasikan kepada pembimbing. Subjek dalam penelitian ini yakni peserta didik kelas XI TBSM (Teknik Bisnis Sepeda Motor) 2 yang terdiri dari 35 peserta didik yang diambil secara acak dari seluruh siswa kelas XI SMK Negeri 2 Tulungagung. Instrumen yang digunakan dalam penelitian ini adalah:

1. Lembar Observasi Kegiatan Guru

Lembar observasi kegiatan guru digunakan untuk mendapatkan data tentang kegiatan guru matematika berbasis daring yang berisi kegiatan guru di dalam kelas. Lembar observasi ini diisi oleh guru mata pelajaran matematika di kelas tersebut dengan memperhatikan peneliti yang bertindak sebagai guru selama proses pembelajaran berlangsung melalui aplikasi Google Meet. Lembar observasi ini sudah dikonsultasikan dengan pembimbing.

\section{Lembar Observasi Kegiatan Peserta Didik \\ Lembar observasi kegiatan peserta didik} digunakan untuk mendapatkan data tentang kegiatan peserta didik sepanjang pembelajaran berlangsung. Lembar observasi ini berisi tentang wujud kegiatan yang dilakukan peserta didik sepanjang mengikuti proses pembelajaran di kelas pada pembelajaran daring. Lembar observasi ini diisi oleh peneliti yang bertindak sebagai guru dengan mencermati kegiatan peserta didik sepanjang proses pembelajaran berlangsung melalui aplikasi Google Meet. Lembar observasi ini sudah dikonsultasikan dengan pembimbing.

3. Lembar Tes Belajar

Lembar tes belajar digunakan untuk mendapatkan data ketuntasan belajar peserta didik dan untuk mengukur ketuntasan belajar klasikal ataupun individu peserta didik dalam menguasai materi yang diajarkan sepanjang proses pembelajaran daring. Lembar tes belajar diberikan kepada peserta didik melalui aplikasi Google Classroom dengan kode Google Classroom 73skt4d. Lembar tes ini sudah dikonsultasikan dengan pembimbing.

4. Lembar Angket Respon Peserta Didik

Lembar angket respon peserta didik digunakan untuk mendapatkan data tentang komentar ataupun asumsi peserta didik terhadap kegiatan pembelajaran daring. Lembar angket respon peserta didik diberikan kepada peserta didik melalui aplikasi Google Classroom dengan mengisi google form yang ada. Lembar angket ini sudah dikonsultasikan dengan pembimbing.

Teknik analisis data yang digunakan dalam penelitian ini adalah sebagai berikut.

1. Analisis Data Kegiatan Guru

Penilaian kegiatan guru diambil dari ratarata kegiatan guru yang dikonversikan dengan kriteria sebagai berikut.

Tabel 1. Kriteria Penilaian Kegiatan Guru

\begin{tabular}{|l|l|l|}
\hline $\begin{array}{l}\text { Tingkat } \\
\text { Penguasaan } \\
(\%)\end{array}$ & Nilai & Kriteria \\
\hline $90-100$ & A & Sangat Baik \\
\hline $80-89$ & B & Baik \\
\hline $70-79$ & C & Cukup \\
\hline
\end{tabular}




\begin{tabular}{|l|l|l|}
\hline $\begin{array}{l}\text { Tingkat } \\
\text { Penguasaan } \\
(\boldsymbol{\%})\end{array}$ & Nilai & Kriteria \\
\hline $60-69$ & $\mathrm{D}$ & Kurang \\
\hline$\leq 59$ & $\mathrm{E}$ & $\begin{array}{l}\text { Perlu } \\
\text { Bimbingan }\end{array}$ \\
\hline
\end{tabular}

(Rima Awarlin, 2019)

Persentase keberhasilan kegiatan guru dapat dihitung dengan rumus sebagai berikut

Persentase keberhasilan aktivitas guru $=$ Jumlah skor yang diperoleh

jumlah skror maksimal

$\mathrm{x} 100 \%$

Kegiatan guru dikatakan efektif apabila persentase keberhasilan untuk setiap keahlian terletak pada kategori minimal "cukup".

2. Analisis Data Kegiatan Peserta Didik

Data kegiatan peserta didik sepanjang pembelajaran berlangsung diambil dari rata-rata kegiatan peserta didik yang dikonversikan dengan kriteria sebagai berikut.

Tabel 2. Kriteria Penilaian Kegiatan Peserta Didik

\begin{tabular}{|l|l|l|}
\hline $\begin{array}{l}\text { Tingkat } \\
\text { Penguasaan } \\
(\%)\end{array}$ & Nilai & Kriteria \\
\hline $90-100$ & A & Sangat Baik \\
\hline $80-89$ & B & Baik \\
\hline $70-79$ & C & Cukup \\
\hline $60-69$ & D & Kurang \\
\hline$\leq 59$ & E & $\begin{array}{l}\text { Perlu } \\
\text { Bimbingan }\end{array}$ \\
\hline
\end{tabular}

(Rima Awarlin, 2019)

Persentase keberhasilan kegiatan peserta didik dapat dihitung dengan rumus sebagai berikut:

Persentase keberhasilan aktivitas siswa = jumlah skor yang dipenoleh

fumlah skror maksimal

$\mathrm{x} 100 \%$

Kegiatan peserta didik dalam melaksanakan pembelajaran dikatakan efektif apabila persentase keberhasilan untuk setiap kegiatan terletak pada kategori minimal "cukup".

3. Analisis Data Ketuntasan Belajar

SMK Negeri 2 Tulungagung menetapkan bahwa Kriteria Ketuntasan Minimal (KKM) untuk mata pelajaran matematika adalah 76 dan ketuntasan klasikal $\geq 85 \%$. Data ketuntasan belajar diperoleh dari aspek pengetahuan. Pada aspek pengetahuan digunakan teknik rata-rata dengan skala 0-100 yang dirumuskan sebagai berikut

\section{Ketuntasan Belajar Klasikal = fwilah siswa yang tuntas \\ Jumlah siswa seluruhnya x $100 \%$.}

4. Analisis Data Respon Peserta Didik

Data tentang respon peserta didik diperoleh dari angket yang dianalisis dengan mencari persentase jawaban peserta didik untuk masingmasing persoalan dalam angket yang dikonversikan dengan kriteria sebagai berikut.

Tabel 3. Kriteria Kepuasan Respon Peserta Didik

\begin{tabular}{|l|l|}
\hline $\begin{array}{l}\text { Tingkat } \\
\text { Kepuasan }(\boldsymbol{\%})\end{array}$ & Kriteria \\
\hline$\geq 85$ & Sangat Positif \\
\hline $70-84$ & Positif \\
\hline $50-69$ & Cukup Positif \\
\hline$<50$ & Kurang Positif \\
\hline
\end{tabular}

(Uun Musfiani, 2013)

Respon peserta didik dianalisis dengan melihat persentase dari respon peserta didik. Persentase ini bisa dihitung dengan memakai rumus:

Persentase respon siswa $=$

Frekuensi diswa yang men jawab ya

Banyak siawa yong mengisi anghet

x $100 \%$

HASIL DAN PEMBAHASAN

Hasil

1. Kegiatan Guru

Data tentang kegiatan guru diperoleh dari pengamatan yang dilakukan oleh peneliti sepanjang empat kali pertemuan. Hasil pengamatan terangkum dalam tabel berikut.

Tabel 4. Hasil Pengamatan Kegiatan Guru

\begin{tabular}{|c|c|c|}
\hline Pertemuan & $\begin{array}{c}\text { Persentase } \\
\mathbf{( \% )}\end{array}$ & $\begin{array}{c}\text { Rata-rata } \\
\mathbf{( \% )}\end{array}$ \\
\hline 1 & $86,67 \%$ & \multirow{2}{*}{$96,6675 \%$} \\
\cline { 1 - 2 } 2 & $100 \%$ & \multirow{2}{*}{} \\
\cline { 1 - 2 } & $100 \%$ & \\
\hline
\end{tabular}




\begin{tabular}{|c|c|c|}
\hline Pertemuan & $\begin{array}{c}\text { Persentase } \\
\mathbf{( \% )}\end{array}$ & $\begin{array}{c}\text { Rata-rata } \\
\mathbf{( \% )}\end{array}$ \\
\hline 4 & $100 \%$ & \\
\hline
\end{tabular}

Berdasarkan hasil kegiatan guru di atas dan sesuai dengan kriteria penilaian, kegiatan guru selama pembelajaran daring dikatakan sangat baik. Kegiatan pembelajaran yang dilakukan oleh guru terdiri dari pembukaan, inti, dan penutup. Kegiatan tersebut dilakukan oleh peneliti sebagai guru saat mengajar melalui aplikasi Google Meet dan diamati oleh guru mata pelajaran matematika di kelas tersebut.

2. Kegiatan Peserta Didik

Data tentang kegiatan peserta didik diperoleh dari pengamatan yang dilakukan oleh satu orang pengamat yakni peneliti. Pengamatan dilakukan sepanjang proses pembelajaran berlangsung sepanjang empat kali pertemuan. Persentase kegiatan peserta didik terangkum dalam tabel berikut.

Tabel 5. Hasil Pengamatan Kegiatan Peserta Didik Sepanjang Proses Pembelajaran

\begin{tabular}{|c|r|r|}
\hline Pertemuan & $\begin{array}{r}\text { Persentase } \\
\mathbf{( \% )}\end{array}$ & $\begin{array}{r}\text { Rata-rata } \\
\mathbf{( \% )}\end{array}$ \\
\hline 1 & $78,57 \%$ & \multirow{2}{*}{$94,6425 \%$} \\
\hline 2 & $100 \%$ & \\
\hline 3 & $100 \%$ & \\
\cline { 1 - 2 } & $100 \%$ & \\
\hline
\end{tabular}

Berdasarkan hasil kegiatan peserta didik di atas dan sesuai dengan kriteria penilaian, kegiatan peserta didik selama pembelajaran daring dikatakan sangat baik. Kegiatan peserta didik dapat diamati saat peserta didik bergabung ke kelas melalui aplikasi Google Meet. Hal ini dapat ditunjukkan saat peserta didik memperhatikan penjelasan dari guru dengan cara mencatat materi.

3. Ketuntasan Belajar Peserta Didik

Data tentang ketuntasan belajar peserta didik diperoleh dari skor tes akhir yang diberikan kepada peserta didik di akhir pertemuan lewat aplikasi Google Classroom. Adapun skor peserta didik untuk materi Persamaan dan Fungsi Kuadrat terangkum dalam tabel berikut.

Tabel 6. Ketuntasan Belajar Peserta Didik

\begin{tabular}{|c|c|c|c|}
\hline No.Absen & Skor & Tuntas & Tidak Tuntas \\
\hline 1 & 57 & & $\sqrt{ }$ \\
\hline 2 & 45 & & $\sqrt{ }$ \\
\hline 3 & 0 & & $\sqrt{ }$ \\
\hline 4 & 57 & & $\sqrt{ }$ \\
\hline 5 & 39 & & $\sqrt{ }$ \\
\hline 6 & 55 & & $\sqrt{ }$ \\
\hline 7 & 60 & & $\sqrt{ }$ \\
\hline 8 & 57 & & $\sqrt{ }$ \\
\hline 9 & 30 & & $\sqrt{ }$ \\
\hline 10 & 45 & & $\sqrt{ }$ \\
\hline 11 & 50 & & $\sqrt{ }$ \\
\hline 12 & 0 & & $\sqrt{ }$ \\
\hline 13 & 34 & & $\sqrt{ }$ \\
\hline 14 & 6 & & $\sqrt{ }$ \\
\hline 15 & 30 & & $\sqrt{ }$ \\
\hline 16 & 30 & & $\sqrt{ }$ \\
\hline 17 & 55 & 1 & $\sqrt{ }$ \\
\hline 18 & 57 & & $\sqrt{ }$ \\
\hline 19 & 50 & & $\sqrt{ }$ \\
\hline 20 & 57 & & $\sqrt{ }$ \\
\hline 21 & 32 & & $\sqrt{ }$ \\
\hline 22 & 57 & $d y /$ & $\sqrt{ }$ \\
\hline 23 & 57 & & $\sqrt{ }$ \\
\hline 24 & 0 & & $\sqrt{ }$ \\
\hline 25 & 57 & & $\sqrt{ }$ \\
\hline 26 & 39 & & $\sqrt{ }$ \\
\hline 27 & 57 & & $\sqrt{ }$ \\
\hline 28 & 41 & & $\sqrt{ }$ \\
\hline 29 & 55 & & $\sqrt{ }$ \\
\hline
\end{tabular}




\begin{tabular}{|c|c|c|c|}
\hline No.Absen & Skor & Tuntas & Tidak Tuntas \\
\hline 30 & 22 & & $\sqrt{ }$ \\
\hline 31 & 57 & & $\sqrt{ }$ \\
\hline 32 & 0 & & $\sqrt{ }$ \\
\hline 33 & 53 & & $\sqrt{ }$ \\
\hline 34 & 20 & & $\sqrt{ }$ \\
\hline 35 & 41 & & $\sqrt{ }$ \\
\hline Rata-rata & 40 & & \\
\hline
\end{tabular}

Menurut tabel di atas diperoleh ketuntasan belajar peserta didik dari 35 peserta didik yang mengikuti tes akhir, semuanya tidak tuntas dengan tingkatan ketuntasan belajar secara klasikal ialah $0 \%$. Menurut kriteria ketuntasan, tes belajar peserta didik dikatakan tidak tuntas.

\section{Respon Peserta Didik}

Data tentang respon peserta didik terhadap kegiatan pembelajaran didapatkan dari angket yang dibagikan kepada tiap peserta didik lewat aplikasi Google Classroom dengan mengisi google form yang ada. Hasil respon peserta didik terhadap kegiatan pembelajaran terangkum dalam tabel berikut.

Tabel 7. Respon Peserta Didik terhadap Kegiatan

\begin{tabular}{|l|l|l|c|c|}
\hline \multirow{5}{*}{ No. } & $\begin{array}{c}\text { Respon } \\
\text { Peserta } \\
\text { didik }\end{array}$ & \multicolumn{2}{|l|}{ Persentase (\%) } \\
\cline { 2 - 5 } & Ya & Tidak & Ya & Tidak \\
\hline 1. & 12 & 15 & $44,44 \%$ & $55,56 \%$ \\
\hline 2. & 11 & 17 & $39,28 \%$ & $60,72 \%$ \\
\hline 3. & 3 & 24 & $11.11 \%$ & $88,89 \%$ \\
\hline 4. & 24 & 5 & $82,75 \%$ & $17,25 \%$ \\
\hline 5. & 8 & 20 & $28,57 \%$ & $71,43 \%$ \\
\hline 6. & 17 & 11 & $60,72 \%$ & $39,28 \%$ \\
\hline 7. & 5 & 22 & $18,51 \%$ & $81,49 \%$ \\
\hline 8. & 21 & 9 & $70 \%$ & $30 \%$ \\
\hline 9. & 7 & 20 & $25,92 \%$ & $74,08 \%$ \\
\hline 10. & 22 & 8 & $73,33 \%$ & $26,67 \%$ \\
\hline
\end{tabular}

Berdasarkan tabel di atas dapat dilihat dari pernyataan positif dengan rata-rata persentase yakni $27,97167 \%$. Sesuai dengan kriteria kepuasan, respon peserta didik terhadap pembelajaran daring dikatakan kurang positif.

Pencapaian keefektifan pembelajaran daring ditentukan berdasarkan data kegiatan guru, kegiatan peserta didik, ketuntasan belajar peserta didik, dan respon peserta didik sepanjang kegiatan pembelajaran berlangsung. Adapun hasil pencapaian keefektifan pembelajaran daring terangkum dalam tabel berikut.

Tabel 8. Pencapaian Keefektifan Pembelajaran

Daring

\begin{tabular}{|l|l|l|}
\hline No. & Aspek yang Diamati & \multicolumn{1}{|c|}{ Kesimpulan } \\
\hline 1. & Kegiatan guru & Sangat Baik \\
\hline 2. & Kegiatan peserta didik & Sangat Baik \\
\hline 3. & $\begin{array}{c}\text { Ketuntasan belajar } \\
\text { peserta didik }\end{array}$ & Tidak Tuntas \\
\hline 4. & Respon peserta didik & Kurang Positif \\
\hline \multicolumn{3}{|c|}{ Menurut tabel di atas dapat disimpulkan }
\end{tabular}

kalau pembelajaran daring pada materi persamaan dan fungsi kuadrat dikatakan tidak efektif. Sesuai dengan kriteria keefektifan, suatu pembelajaran dikatakan efektif jika paling sedikit tiga aspek dari empat aspek di atas dipenuhi, dengan ketentuan aspek ketuntasan belajar klasikal tuntas terpenuhi.

\section{Pembahasan}

Dari hasil pengamatan yang dilakukan peneliti sebanyak empat kali pertemuan lewat pengamatan (observasi) serta sebaran angket, diperoleh sebagian hasil pengamatan yang berlandaskan tabel kegiatan guru, kegiatan peserta didik, ketuntasan belajar peserta didik, dan respon peserta didik sepanjang pembelajaran daring. Adapun hasil dari pengamatan dalam penelitian ini adalah sebagai berikut:

\section{Kegiatan Guru}

Menurut hasil pengamatan penelitian, dapat diketahui jika dalam mengelola pembelajaran dengan daring, guru melakukan pembelajaran dengan baik. Pada pertemuan pertama memperoleh persentase sebesar $86,67 \%$, perihal ini diakibatkan oleh model pembelajaran yang digunakan ialah model pembelajaran Discovery Learning yang berpusat pada peserta didik. Sebaliknya pada pertemuan kedua hingga ke empat memperoleh persentase sebesar $100 \%$, perihal ini diakibatkan oleh model pembelajaran yang digunakan ialah model pembelajaran langsung yang berpusat pada penjelasan guru.

Mengingat guru pada sekolah tersebut jarang sekali yang menggunakan model pembelajaran yang berpusat pada peserta didik, maka model pembelajaran langsung yang biasanya diterapkan di sekolah. Kegiatan pembelajaran yang dilakukan oleh 
guru terdiri dari pembukaan, inti, dan penutup. Kegiatan tersebut dilakukan oleh peneliti sebagai guru saat mengajar melalui aplikasi Google Meet dan diamati oleh guru mata pelajaran matematika di kelas tersebut.

\section{Kegiatan Peserta Didik}

Menurut hasil pengamatan penelitian, dapat diketahui jika kegiatan yang kerap dilakukan peserta didik sepanjang proses pembelajaran ialah mendengarkan ataupun memperhatikan penjelasan guru. Perihal ini dapat dilihat pada saat peserta didik mengumpulkan tugas di Google Classroom tepat waktu, mengumpulkan buku catatan ke sekolah, dan juga ketika guru bertanya kembali pada peserta didik. Mengingat model pembelajaran yang digunakan ialah model pembelajaran langsung yang berpusat pada penjelasan guru.

Tetapi, pada pertemuan pertama ketika guru meminta peserta didik mengerjakan LKPD mereka mengalami kesulitan. Ketika mereka diminta mempresentasikan hasil pekerjaan di LKPD, mereka kebingungan. Hal ini disebabkan karena model pembelajaran yang diterapkan di sekolah tersebut adalah model pembelajaran langsung yang berpusat pada guru. Akibatnya mereka tidak terbiasa dengan model pembelajaran yang berpusat pada peserta didik dari kebiasaan tadi. Selain itu, mereka juga belum terbiasa dengan adanya pembelajaran daring yang belum diterapkan sepenuhnya di sekolah.

\section{Ketuntasan Belajar Peserta Didik}

Berdasarkan tabel 6 dapat dilihat kalau dari 35 peserta didik yang mengikuti tes akhir, seluruhnya tidak tuntas dengan tingkatan ketuntasan belajar secara klasikal ialah 0\%. Perihal ini diakibatkan mereka susah memahami ataupun menguasai materi yang diajarkan oleh guru serta tidak sungguhsungguh dalam menerima pelajaran. Mengingat peserta didik belajar di rumah sehingga tidak menutup kemungkinan jika tugas maupun ulangan harian peserta didik dibantu oleh teman.

Menurut kriteria ketuntasan belajar klasikal yakni apabila peserta didik dalam kelas sudah menggapai ketuntasan belajar sebesar $\geq 85 \%$ maka ketuntasan belajar secara klasikal pada materi pokok persamaan dan fungsi kuadrat dikatakan tuntas. Pembelajaran daring pada penelitian ini mempunyai ketuntasan belajar secara klasikal sebesar 0\% serta tidak melebihi standar yang dipunyai yakni $\geq 85 \%$. Sehingga pembelajaran daring pada materi pokok persamaan dan fungsi kuadrat secara klasikal dikatakan tidak tuntas.

\section{Respon Peserta Didik}

Menurut hasil pengamatan yang ada, maka bisa diketahui kalau atensi peserta didik terhadap pembelajaran daring kurang positif. Peserta didik tidak mengharapkan pembelajaran semacam ini diterapkan kembali, sebab dengan pembelajaran semacam ini mereka tidak bisa memahami ataupun menguasai materi yang diajarkan oleh guru. Perihal ini cocok dengan data hasil penelitian yang ada pada tabel 7.

Dari tabel 7 dapat dilihat jika rata-rata persentase Respon positif peserta didik sebesar $27,97167 \%$. Sehingga dari hasil rata-rata persentase Respon dapat disimpulkan kalau Respon peserta didik terhadap pembelajaran daring kurang positif.

Bersumber pada penjelasan uraian di atas bisa dilihat bahwa kegiatan guru dalam mengelola pembelajaran daring dikatakan sangat baik, kegiatan peserta didik dalam melaksanakan pembelajaran daring dikategorikan sangat baik, ketuntasan belajar peserta didik pada pembelajaran daring dikategorikan tidak tuntas, dan Respon peserta didik terhadap pembelajaran daring dikategorikan kurang positif.

Menurut Christiani (2013) untuk mengukur efektivitas pembelajaran ini ditetapkan empat indikator, yakni:

1. Kegiatan guru dikategorikan baik;

2. Kegiatan peserta didik dikategorikan baik;

3. Ketuntasan belajar peserta didik tuntas secara klasikal;

4. Respon peserta didik dikategorikan positif

Bila tiga dari keempat indikator tersebut terpenuhi, dengan ketentuan indikator nomor tiga harus ikut didalamnya, maka pembelajaran daring pada materi persamaan dan fungsi kuadrat dapat dikatakan efektif. Sehingga dari penjelasan hasil penelitian serta ulasan di atas bisa dikatakan kalau pembelajaran daring pada materi persamaan dan fungsi kuadrat dikatakan tidak efektif. Hal ini disebabkan berbagai faktor, diantaranya kurangnya penjelasan yang komprehensif dan sederhana dari guru, rendahnya aspek afektif dan psikomotorik pada pembelajaran, sinyal internet, rendahnya minat peserta didik terhadap pembelajaran daring, dan pembelajaran daring belum diterapkan sepenuhnya di sekolah. 
Hal ini sejalan dengan penelitian Mega Berliana Yolandasari (2020) yang menyatakan bahwa pelaksanaan pembelajaran daring dalam pembelajaran Bahasa Indonesia di kelas II A kurang efektif, penelitian Jagad Aditya Dewantara (2021) yang menyatakan bahwa pembelajaran daring secara terus menerus selama masa pandemi ini sangat tidak efektif dan juga penelitian Selvi Loviana (2020) yang menyatakan bahwa pembelajaran daring kurang efektif. Namun hal ini berbeda dengan penelitian Nurul Astuty Yensy (2020) menunjukkan bahwa media Whatsapp Group cukup efektif jika dilihat dari ketuntasan belajar peserta didik.

Kurang efektifnya pembelajaran daring pada materi persamaan dan fungsi kuadrat, menuntut guru untuk lebih kreatif dan inovatif dalam menyampaikan materi kepada peserta didik. Dalam pelaksanaan pembelajaran hendaknya guru menggunakan media pembelajaran yang memudahkan peserta didik memahami materi agar pembelajaran tetap efektif walaupun dilaksanakan secara daring.

\section{PENUTUP}

\section{Simpulan}

Menurut hasil analisis data penelitian diperoleh simpulan jika pembelajaran daring pada materi persamaan dan fungsi kuadrat secara umum dikatakan tidak efektif karena tidak tuntasnya hasil belajar peserta didik dan kurang positifnya respon peserta didik terhadap pembelajaran. Perihal ini diakibatkan bermacam aspek, antara lain minimnya uraian yang komprehensif serta sederhana dari guru karena pada penelitian ini guru menjelaskannya terlalu panjang sehingga peserta didik kesulitan memahami materi yang diberikan dan diperlukan menggunakan media yang menarik untuk belajar mandiri seperti video pembelajaran dan game matematika, rendahnya aspek afektif serta psikomotorik pada pembelajaran dimana peserta didik kesulitan dalam mengerjakan tes hasil belajar, sinyal internet, rendahnya atensi peserta didik terhadap pembelajaran daring, serta pembelajaran daring belum diterapkan sepenuhnya di sekolah.

\section{Saran}

Bersumber dari hasil dan pelaksanaan penelitian yang diperoleh, sehingga penulis bisa memberikan masukan sebagai berikut: 1). Diperlukan penelitian lebih lanjut untuk mempraktikkan pembelajaran daring untuk kelas dan materi yang berbeda maupun sama sebab pada penelitian ini pembelajaran daring pada materi pokok persamaan dan fungsi kuadrat dikatakan tidak efektif.

\section{DAFTAR PUSTAKA}

Anugrahana, Andri. 2020. "Hambatan, Solusi, dan Harapan: Pembelajaran FDaring Selama Masa Pandemi Covid-19 Oleh Guru Sekolah Dasar". Scholaria: Jurnal Pendidikan dan Kebudayaan. Vol 10 (3).

Anwar, Zul. 2012. "Pelaksanaan Pembelajaran Matematika di Sekolah Dasar". Jurnal Penelitian Ilmu Pendidikan. Vol 5 (2).

Awarlin, Rima. 2019. Efektivitas Model Jigsaw dengan Two Stay Two Stray pada Materi FPB dan KPK di Kelas IV SDN Bendo I. Skripsi tidak diterbitkan. Malang: Universitas Negeri Malang.

Christiani, Vivi. 2013. "Efektivitas Pembelajaran Kooperatif dengan strategi Berwisata pada Materi Persegipanjang dan Persegi di Kelas VII SMP”. Jurnal Mathedunesa. Vol 2 (1).

Darmalaksana, W., Hambali, R. Y. A., Masrur, A., \& Muhlas. 2020. "Analisis Pembelajaran Online Masa WFH Pandemic Covid-19 sebagai Tantangan Pemimpin Digital Abad 21". Karya Tulis Ilmiah (KTI) Masa Work From Home (WFH) Covid-19. Vol 1 (1).

Dewantara, J., T. H. Nurgiansah. 2021. "Efektivitas Pembelajaran Daring di Masa Pandemi Covid-19 bagi Mahapeserta didik Universitas PGRI Yogyakarta". Jurnal Basicedu. Vol 5 (1).

Dewi, L. 2017. "Rancangan Program Pembelajaran Daring di Perguruan Tinggi: Studi Kasus pada Mata Kuliah Kurikulum Pembelajaran di Universitas Pendidikan Indonesia". Edutech. Vol 16 (2).

Dewi, W. A. F. 2020. "Dampak COVID-19 Terhadap Implementasi Pembelajaran Daring di Sekolah Dasar". Edukatif: Jurnal Ilmu Pendidikan. Vol 2 (1).

Fitriyani, Y., dkk. 2020. "Motivasi Belajar Mahapeserta didik Pada Pembelajaran Daring Selama Pandemik Covid-19”. Jurnal Kependidikan: Jurnal Hasil Penelitian dan 
Kajian Kepustakaan di Bidang Pendidikan, Pengajaran dan Pembelajaran. Vol 6 (2).

Loviana, Selvi. 2020. "Dampak Pandemi Covid-19 pada Kesiapan Pembelajaran Tadris Matematika IAIN Metro Lampung”. Jurnal Epsilon. Vol 2 (1).

Menteri Pendidikan dan Kebudayaan Republik Indonesia. (2020). Surat Edaran Nomor 4 Tahun 2020 tentang Pelaksanaan Kebijakan Pendidikan dalam Masa Darurat Penyebaran Coronavirus Disease (COVID-19).

Musfiani, Uun. 2013. "Efektivitas Model Pembelajaran Kooperatif Tipe NHT (Number Head Together) Menggunakan Teknik Probing pada Materi Luas Permukaan Kubus dan Balok di Kelas VIII SMPN 1 Balongbendo". Jurnal Mathedunesa. Vol 2 (1).

Nurani, Najila Indah., dkk. 2020. “Analisis Proses Pembelajaran daring Menggunakan Aplikasi Google Classroom pada Masa Pandemi Covid-19”. Jurnal PGSD. Vol 6 (1).

Permendikbud. 2013. Peraturan Menteri Pendidikan dan Kebudayaan Nomor 65 Tahun 2013 Tentang Pemanfaatan Teknologi Informasi Untuk Meningkatkan Efisiensi Dan Efektifitas Pembelajaran. Jakarta: Permendikbud.
Siswono, Tatag Yuli Eko. 2019. Paradigma Penelitian Pendidikan. Bandung: Remaja Rosdakarya.

Suharwoto, Gogot. 2020. Pembelajaran Online di Tengah Pandemi Covid-19, Tantangan yang Mendewasakan. Jakarta: Kemendikbud. Retrieved from https://pusdatin.kemdikbud.go.id/pembelajar an-online-di-tengah-pandemi-covid-19tantangan-yang-mendewasakan/.

Windhiyana, E. 2020. "Dampak Covid-19 Terhadap Kegiatan Pembelajaran Online Di Perguruan Tinggi Kristen Di Indonesia". Jurnal Perspektif Ilmu Pendidikan. Vol 34 (1).

Wiryanto. 2020. "Proses pembelajaran Matematika di Sekolah Dasar di Tengah Pandemi Covid19".Jurnal Review Pendidikan Dasar: Jurnal Kajian Pendidikan dan Hasil Penelitian. Vol 6 (2).

Yensy, Nurul Astuty. 2020. "Efektivitas Pembelajaran Statistika Matematika melalui Whatsapp Group Ditinjau dari Ketuntasan belajar Mahapeserta didik (Masa Pandemik Covid-19)". Jurnal Pendidikan Matematika Raflesia. Vol 5 (2).

Yolandasari, Mega Berliana. 2020. Efektivitas Pembelajaran Daring dalam Pembelajaran Bahasa Indonesia di Kelas II A MI Unggulan Miftahul Huda Tumang Cepogo Boyolali Tahun Pelajaran 2019/2020. 